\title{
Perlindungan Hukum Bagi Kreditor Terhadap Hapusnya Hak Atas Tanah yang Dibebani Hak Tanggungan
}

\section{Dewa Gede Arie Kusumaningrat ${ }^{1}$}

\author{
${ }^{1}$ Program Studi Magister Kenotariatan, Fakultas Hukum Universitas Udayana,
} E-mail: dewaarie7@gmail.com

\begin{tabular}{l}
\hline Info Artikel \\
\hline Masuk: 27 Mei 2019 \\
Diterima : 28 Juni 2019 \\
Terbit: 21 Juli 2019 \\
Keywords : \\
Legal protection; Credit, \\
Guarantees \\
\\
\\
\\
Kata kunci: \\
Perlindungan hukum; kredit; \\
jaminan \\
Corresponding Author: \\
I Dewa Gede Arie \\
dewaruarie7@gmail.com \\
DOI : \\
10.24843/AC.2019.v04.02.p.08 \\
\end{tabular}

\begin{abstract}
Credit distribution by banks is one effort that can be utilized by everyone to meet needs that are very diverse and always increasing. Credit distribution by banks is generally carried out in the presence of collateral to increase creditor trust. Credit distribution is a product that is profitable for the bank, but on the other hand there is a risk in lending due to the need for time from the lending phase to the repayment stage. Credit implementation does not always run smoothly, one of which is when the credit debtor becomes bogged down, plus the collateral of the debtor cannot be executed by the bank because the guarantee has been removed by a certain matter. The problem is how the legal protection for creditors against the abolition of land rights burdened with liability and how the debtor's responsibility due to the abolition of rights to land burdened with mortgage rights. Normative juridical research used in compiling this study is accompanied by the use of a legal approach (Statue approach), and a conceptual approach. There are two types of protection for creditors, namely preventive legal protection (prevention) and repressive legal protection (dispute resolution). The debtor is still obliged to pay off the debt even though the collateral with the right of liability has been removed. The credit agreement is a protection for creditors in the event of a dispute during the process of lending, then efforts can be made by the bank if there is a problem, namely by conducting a credit restructuring.
\end{abstract}

\begin{tabular}{l}
\hline Abstrak \\
\hline Penyaluran kredit oleh bank merupakan salah satu upaya yang \\
dapat dimanfaatkan oleh setiap orang guna memenuhi kebutuhan \\
yang sangat beraneka ragam dan selalu meningkat. Penyaluran \\
kredit oleh bank pada umumnya dilakukan dengan keberadaan \\
jaminan guna meningkatkan kepercayaan kreditor. Penyaluran \\
kredit merupakan produk yang menguntungkan bagi bank, \\
namun disisi lain terdapat resiko dalam penyaluran kredit \\
tersebut yang dikarenakan diperlukannya waktu sejak tahap \\
pemberian kredit sampai pada tahap pelunasan kredit. Pelaksaan \\
kredit tidak selalu berjalan dengan lancar, salah satunya ketika \\
debitor kreditnya menjadi macet, ditambah lagi jaminan debitor \\
tidak bisa dieksekusi oleh bank karena jaminan telah hapus oleh \\
suatu hal tertentu. Adapun yang menjadi masalah yakni \\
bagaimana perlindungan hukum bagi kreditor terhadap \\
hapusnya hak atas tanah yang dibebani hak tanggungan dan
\end{tabular}


bagaimana tanggung jawab debitor akibat hapusnya hak atas tanah yang dibebani hak tanggungan. Penelitian normatif digunakan dalam menyusun penelitian ini disertai penggunaan pendekatan perundang-undangan (Statue approach), dan pendekatan konseptual (conceptual approach). Terdapat dua jenis perlindungan bagi kreditor yaitu perlindungan hukum preventif (pencegahan) serta perlindungan hukum represif (penyelesaian sengketa). Debitor tetap berkewajiban melunasi utangnya meskipun jaminan dengan hak tanggungan telah hapus. Perjanjian kredit menjadi perlindungan bagi kreditor dalam hal terjadinya sengketa selama proses penyaluran kredit, kemudian upaya yang dapat dilakukan bank apabila terjadi permasalahan yakni dengan melakukan restrukturisasi kredit.

\section{Pendahuluan}

Kepercayaan dari masyarakat merupakan hal utama yang sangat diperlukan terhadap eksistensi bank sebagai lembaga yang bergerak di bidang keuangan, karena pada dasarnya bank dengan masyarakat saling membutuhkan. Pada prinsipnya bank dan masyarakat saling membutuhkan, bank membutuhkan masyarakat untuk dapat menjalankan kegiatan usahanya, sedangkan masyarakat membutuhkan bank berkaitan dengan bidang keuangan dengan memanfaatkan jasa-jasa yang disediakan oleh bank. Fungsi utama dari bank yaitu melakukan penghimpunan dan penyaluran dana dari masyarakat dan kepada masyarakat juga melalui jasa-jasa yang disediakan seperti simpanan dan pelayanan kredit. Kehadiran bank juga diharapkan mampu untuk meningkatkan taraf kehidupan masyarakat menuju ke arah kesejahteraan. ${ }^{1}$

Pelaksanaan kredit dapat dikatakan sebagai kegiatan utama bank yang berpengaruh terhadap kesehatan dan kelangsungan usaha bank. ${ }^{2}$ Tidak bisa dipungkiri bahwa keuntungan terbesar yang didapat dari bank bersumber dari penyaluran kredit kepada masyarakat dibandingkan dengan produk dan jasa perbankan lainnya. Penyaluran kredit merupakan suatu fungsi yang dapat dikatakan menguntungkan kedua belah pihak baik itu bank maupun masyarakat, hal ini dikarenakan bank akan diutungkan dengan adanya bunga yang harus dibayarkan oleh masyarakat yang memohon kredit kepada bank dan disisi lain masyarakat akan mendapatkan dana yang dapat dimanfaatkan untuk berbagai hal seperti halnya pembangunan ataupun pengembangan suatu usaha.

Pemahaman mengenai kredit dapat ditemukan dalam ketentuan Pasal 1 angka 11 Undang-Undang perbankan yang pada intinya memberikan pemahaman kredit sebagai kesepakatan antara bank dengan pihak lain terkait dengan kemampuan bank untuk meminjamkan uang kepada pihak lain tersebut disertai dengan janji jika uang tersebut akan dikembalikan pada suatu waktu tertentu sesuai dengan kesepakatan yang telah dibuat. Dari definisi tersebut dapat dipahami bahwa dengan adanya kredit maka terjadi suatu kesepakatan yang menimbulkan hubungan hokum antara bank dan

1 Pato, S. (2013). Analisis Pemberian Kredit Mikro Pada Bank Syariah Mandiri Cabang Manado. Jurnal EMBA: Jurnal Riset Ekonomi, Manajemen, Bisnis dan Akuntansi, 1(4). hal.1

2 Sari, G. N. (2013). Faktor-faktor yang mempengaruhi penyaluran kredit bank umum di Indonesia (periode 2008.1-2012.2). Jurnal EMBA: Jurnal Riset Ekonomi, Manajemen, Bisnis dan Akuntansi, 1(3).hal.933 
masyarakat peminjam kredit dimana bank sebagai pemberi pinjaman atau kreditor sedangkan masyarakat sebagai pihak yang meminjam dana atau debitor.

Secara etimologis kata kredit diambil dari istilah latin credere atau diartikan sebagai kepercayaan. ${ }^{3}$ Unsur kepercayaan menjadi faktor utama penyaluran kredit oleh bank kepada masyarakat, makna kepercayaan ini yakni keyakinan bank bahwa dana yang disalurkannya akan kembali sesuai dengan kesepakatan yang disepaktai dengan masyarakat atau debitor sebagai penerima pinjaman dana. Selain unsur kepercayaan, terdapat unsur-unsur lain yang memberikan pengaruh dalam penyaluran kredit, adapun antara lain tenggang waktu, tingkat resiko yang dihadapi oleh bank, prestasi atau objek kredit. Dalam suatu penyaluran kredit maka pada umumnya diperlukan suatu persetujuan kehendak melalui pembentukan perjanjian antar pihak, yang berisikan mengenai hak serta kewajiban kreditor dan debitor selama proses kredit ini berlangsung, disamping itu perjanjian juga dapat dijadikan sebagai dasar untuk mengajukan gugatan kepada salah satu pihak apabila terjadi suatu tindakan yang merugikan atau tindakan wanprestasi.

Kepercayaan merupakan unsur penting dalam penyaluran kredit, pemberian kredit haruslah didasarkan atas keyakinan dari kreditor bahwa dana yang disalurkan akan sanggup dikembalikan oleh debitor sesuai kesepakatan tenggang waktu yang ditentukan dalam perjanjian, oleh karenanya dalam menyalurkan kredit bank selaku kreditor juga harus memperhatikan asas-asas perkreditan dimana untuk dapat meningkatkan kepercayaan kepada debitor maka bank harus bias melakukan penilaian terhadap calon debitor, adapun dalam penyaluran kredit dikenal asas $5 \mathrm{c}$ atau yakni hal hal dasar yang harus menjadi pokok bank ketika hendak menyalurkan kredit, asasasas 5 c dijelaskan sebagai berikut :4

1. Charakter (karakter/watak)

Karakter dari calon debitor haruslah dapat dinilai sebaik mungkin oleh bank, debitor harus memiliki karakter atau watak disertai moral yang baik, dengan demikian dapat meningkatkan kepercayaan bank.

2. Capacity (kemampuan)

Kemampuan dari calon debitor kaitannya dengan pengelolaan kegiatan atau usaha dari calon debitor tersebut, apabila kegiatan atau usaha dari calon debitor tersebut memiliki prospektif yang baik tentunya dapat sebagai jaminan bahwa dana yang disalurkan oleh bank akan dapat kembali lagi.

3. Capital (modal)

Capital atau modal kaitannya dengan dana awal ditempatkan oleh calon debitor, dengan demikian dapat dilakukan jika sumber-sumber yang telah dimiliki dapat dilaksanakan dengan efektif.

4. Collateral (jaminan/agunan)

Jaminan atau agunan menjadi satu hal penting, keberadaan jaminan meningkatkan kepercayaan bank. Apabila debitor tersebut melakukan wanprestasi di kemudian hari maka bank memiliki kewenangan untuk mengeksekusi jaminan tersebut sehingga akan mendapatkan uang dari hasil eksekusi tersebut yang digunakan untuk menutupi kredit macet dari

\footnotetext{
${ }^{3}$ Djoni S.Gazali \& Rachmadi Usman, 2012, Hukum Perbankan, Sinar Grafika, Jakarta, hal.263.

${ }^{4}$ Ibid, hal.273.
} 
debitor yang melakukan wanprestasi sehingga bank akan terhindar dari kerugian.

5. Condition of Economy (kondisi ekonomi)

Kondisi ekonomi harus diperhatikan dengan seksama guna menghindari resiko yang dapat terjadi karena kondisi ekonomi yang tidak menentu.

Kelima poin penting diatas merupakan asas-asas perkreditan. Pada prakteknya guna meningkatkan kepercayaan kreditor kepada debitor, suatu agunan atau jaminan merupakan hal yang sangat penting guna menjamin bahwa dana yang disalurkan itu akan kembali atau dapat dikatakan bahwa fungsi agunan adalah sebagai pengamanan atas penyaluran dana dari bank kepada masyarakat selaku debitor.

Bank dalam menjalankan tugasnya yakni penyaluran dana berupa kredit maka harus memperhatikan objek yang dijaminkan oleh kreditor, adanya jaminan akan berkaitan dengan keamanan dari bank itu sendiri yakni pelunasan utang. ${ }^{5}$ Debitor dalam memberikan jaminan tentu didasari pemikiran bahwa objek yang diserahkan sebagai jaminan tersebut tidak akan mengganggu operasional usahanya, sedangkan bagi bank jaminan yang diharapkan tentu berupa objek yang memiliki nilai sesuai dengan dana yang disalurkan sehingga dapat menimbulkan rasa aman bagi bank karena tumbuh keyakinan dana yang disalurkan tersebut akan kembali sesuai waktu yang disepakati. ${ }^{6}$ Pada umumnya jaminan yang dapat dikategorikan sebagai jaminan yang aman bagi bank adalah hak atas tanah. Jaminan berupa hak atas tanah tidak bisa dipungkiri memiliki nilai ekonomis yang baik dibandingkan dengan objek lain. Jaminan berupa hak atas tanah akan dibebankan hak tanggungan sesuai dengan ketentuan pasal 4 ayat (1) Undang-Undang Hak Tanggungan.

Seperti yang telah dijelaskan sebelumnya bahwa hak atas tanah merupakan jaminan yang baik bagi bank, namun selalu terdapat resiko yang dihadapi oleh bank selaku kreditor, Bank selalu dihadapkan dengan resiko saat menjalankan kegiatan usahanya di bidang penyaluran kredit khususnya jangka waktu hingga dana yang disalurkan tersebut kembali. ${ }^{7}$ Tanah dapat musnah atau hilang karena adanya bencana alam sehingga dapat menyebabkan hapusnya hak atas tanah tersebut, dengan hapusnya hak atas tanah tentu akan menghilangkan objek jaminan dalam suatu kegiatan kredit yang tentunya akan menyebabkan permasalahan karena akan menghapus hak tanggungan juga, hal ini merupakan salah satu contoh resiko yang bisa dihadapi oleh bank dalam kegiatan kredit tersebut. Disamping itu Undang-Undang hak tanggungan juga mengatur mengenai hal-hal yang dapat menyebabkan hapusnya hak atas tanah sesuai dengan pasalpasal 27, pasal 34, serta pasal 40. Hilangnya jaminan debitor atas kreditnya kepada kreditor karena suatu hal tertentu tentunya dapat merugikan kreditor karena keamanan dari dana yang disalurkannya tersebut tidak memiliki jaminan akan kembali dan hal ini bisa menimbulkan kondisi yang semakin buruk

\footnotetext{
${ }_{5}^{5}$ Pertiwi, d. (2013). Perlindungan hukum pemegang hak tanggungan yang obyeknya dikuasai pihak ketiga berdasarkan perjanjian sewa menyewa. Calyptra, 2(2), 1-16.hal.3.

6 Winarno, J. (2013). Perlindungan Hukum bagi Kreditor pada Perjanjian Jaminan Fidusia. Jurnal Independent, 1(1), hal.44

${ }^{7}$ Ivana, M. (2013). Restrukturisasi Kredit oleh PT. Bank Rakyat Indonesia (Persero) Tbk Cabang Kawi Malang terhadap Perusahaan Otobus Putra Mulia Berkedudukan di Kabupaten Malang (Studi Implementasi Surat Keputusan Direksi PT. Bank Rakyat Indonesia No: S. 94dir/adk/12/2005 T. Kumpulan Jurnal Mahasiswa Fakultas Hukum, 1(4). hal.3
} 
apabila debitor memiliki itikad tidak baik untuk tidak mengembalikan dana yang dipinjamnya tersebut.

\section{Metode Penelitian}

Jenis penelitian yuridis normatif merupakan penelitian yang digunakan dalam penelitian ini disertai dengan penggunaan pendekatan perundang-undangan (Statue approach) dan pendekatan konsep (conceptual approach). Penelitian ini dilakukan dengan cara dengan cara meneliti bahan kepustakaan yang ada seperti peraturan perundangundangan, buku-buku yang berkaitan dengan isu yang akan dipecahkan, serta kamus dan ensiklopedi. ${ }^{8}$ Penelitian ini dimaksudkan guna mendapatkan informasi yang relevan dari berbagai aspek sehingga akan dapat membantu peneliti dalam memecahkan isu yang sedang ditangani. Salah satu hal penting dalam melakukan penelitian adalah penggunaan pendekatan dimana dalam penelitian dikenal beberapa jenis pendekatan, dalam penelitian ini

Penelitian ini menggunakan tiga jenis sumber bahan hukum yaitu bahan hukum primer berupa peraturan perundang-undangan terkait dengan penelitian, bahan hukum sekunder berupa buku-buku, karya ilmiah serta artikel-artikel maupun pendapat ahli di bidang hukum, dan bahan hukum tertier yakni berupa kamus. Selanjutnya terkait dengan Teknik pengumpulan bahan hukum cara yang dipilih yaitu dengan mecatat bahan-bahan yang dianggap relevan dengan permasalahan, kemudian bahan-bahan yang berhasil dikumpulkan tersebut dianalisis dengan Teknik deskriptif.

\section{Hasil dan Pembahasan}

\subsection{Perlindungan Hukum Bagi Kreditor Terhadap Hapusnya Hak Atas Tanah yang Dibebani Hak Tanggungan}

Pada umumnya penyaluran kredit oleh bank kepada masyarakat ditandai adanya penandatanganan perjanjian kredit. Perjanjian kredit merupakan satu hal yang harus diperhatikan oleh pihak kreditor maupun debitor karena perjanjian ini berisikan mengenai hak dan kewajiban dari para pihak selama proses kredit berlangsung seperti besaran bunga yang harus dibayarkan, ataupun biaya lain yang lahir karena perjanjian tersebut. ${ }^{9}$ Pihak debitor berhak atas segala informasi-informasi yang berkaitan dengan proses perkreditan serta mendapatkan fasilitas kredit sesuai dengan informasi yang diterimanya dan berkewajiban untuk melunasi kreditnya tersebut sesuai kesepakatan yang dituangkan dalam perjanjian kredit, sedangkan bagi kreditor berhak mendapatkan kembali dananya yang telah disalurkan tersebut disertai dengan pembayaran bunga dan berkewajiban untuk menyalurkan kredit kepada debitor.

Perjanjian kredit merupakan pedoman bagi kreditor dan debitor dalam bertindak sehingga akan mengetahui batasan yang harus dihormati selama proses perkreditan berlangsung. Seperti yang telah dijelaskan pada bagian sebelumnya, dalam proses perkreditan keberadaan jaminan menjadi faktor penting bagi kreditor karena akan

\footnotetext{
${ }^{8}$ Soekanto, S. \& Mamudji. S., 2009, Penelitian Hukum Normatif Suatu Tinjauan Singkat, PT Raja Grafindo Persada, Jakarta, hal.13-14

9 Hidayat, D. R. (2018). Perlindungan Hukum bagi Kreditor Dengan Jaminan Atas Objek Jaminan Hak Tanggungan Yang Sama. DiH: Jurnal Ilmu Hukum.hal.9
} 
memberikan kedudukan yang kuat dan aman, dengan adanya jaminan dibawah penguasaan kreditor akan memberikan kewenangan bagi kreditor tersebut untuk mengeksekusi jaminan tersebut dalam hal tidak dipenuhinya prestasi oleh debitor atau debitor tersebut melakukan wanprestasi.

Kedudukan kreditor tidak selalu kuat apabila dibandingkan dengan debitor, hal ini dapat terjadi ketika jaminan yang berada pada penguasaan kreditor musnah karena suatu hal tertentu seperti hapusnya hak atas tanah. Dengan musnahnya jaminan tersebut maka akan mengakibatkan kedudukan kreditor menjadi lemah serta meningkatnya resiko kerugian bagi bank. Hal ini dikarenakan kreditor tidak memiliki jaminan yang bisa di eksekusi olehnya apabila terjadi suatu itikad tidak baik dari debitor dengan melakukan wanprestasi atau tidak memenuhi kewajibannya untuk membayar utang kepada bank

Kedudukan bank selaku pemegang jaminan yang dibebani hak tanggungan adalah sebagai kreditor preferent yang mana pada prinsipnya akan diistimewakan atau didahulukan haknya dibandingkan dengan kreditor lain yang tidak memegang hak tanggungan dalam hal terjadi wanprestasi yang dilakukan oleh debitor. Hak tanggungan yang melekat pada objek jaminan akan ikut serta hapus apabila hak atas tanah yang merupakan objek dari jaminan tersebut hapus, dengan demikian kedudukan bank sebagai kreditur preferent akan terdegradasi menjadi kreditur konkuren karena terhapusnya hak tanggungan tersebut, dengan demikian keistimewaan bank karena didahulukan akan hilang sehingga hak-hak bank akan menjadi sama dengan kreditor-kreditor lain, hal ini sesuai dengan ketentuan pasal 1131 dan 1132 KUH Perdata.

Menurut Phillipus M.Hadjon Perlindungan hukum bagi kreditor dalam hal ini terdiri dari dua yakni perlindungan hukum preventif dan represif. ${ }^{10}$ Perlindungan hukum preventif berarti mencegah terjadinya sengketa yakni perlindungan dengan melakukan menyiapkan upaya-upaya pencegahan-pencegahan akan terjadinya suatu sengketa. perlindungan represif disediakan guna penyelesaian dari lahirnya permasalahan akibat terciptanya suatu hubungan hukum. ${ }^{11}$ Perjanjian kredit yang dibentuk pada awal proses perkreditan merupakan perlindungan secara preventif baik bagi kreditor maupun debitor, karena didalamnya terkandung hak dan kewajiban masing-masing yang menjadi pedoman dalam bertindak sehingga mengetahui mana yang dibenarkan atau tidak dibenarkan untuk dilakukan selama proses perkreditan berlangsung. Disamping itu, perlindungan preventif bagi kreditor dalam proses pelaksanaan penyaluran kredit yakni dengan mengasuransikan kredit tersebut kepada lembaga asuransi, pada umumnya cara ini dilakukan dalam upaya untuk melindungi kepentingan kedua belah pihak. ${ }^{12}$

Dilakukannya pendaftaran asuransi oleh bank terhadap kredit yang disalurkan maka akan memberikan keamanan yang lebih bagi bank tersebut, karena apabila terjadi suatu permasalahan dalam proses kredit tersebut maka akan menjadi kewajiban dari Lembaga asuransi untuk penyelesaian kredit berupa pelunasan utang debitor tersebut.

${ }^{10}$ H. Salim \& Erlies Septiana Nurbani, 2017, Penerapan Teori Hukum Pada Tesis dan Disertasi, PT. RajaGrafindo Persada, Jakarta, hal.264

${ }^{11}$ Ibid.

12 Jaya, I. G. P., Utama, I. M. A., \& Westra, I. K. (2015). Kekuatan Hukum Sertifikat Hak Tanggungan Dalam Hal Musnahnya Obyek Hak Tanggungan Karena Bencana Alam. Acta Comitas, 277-285.,hal.283 
Kemudian adanya upaya rekstrukturisasi kredit yang dapat dilakukan oleh kreditor dalam hal terjadinya suatu sengketa merupakan cerminan dari perlindungan secara represif bagi pihak dalam proses perkreditan.

Restruturisasi kredit merupakan upaya-upaya yang dapat dimanfaatkan apabila dalam proses perkreditan debitor tidak mampu memenuhi kewajibannya. ${ }^{13}$ Upaya bank untuk melakukan restrukturisasi ini pada dasarnya guna menghindari terjadinya kerugian bank sekaligus dapat tetap terjaganya kualitas kredit yang disalurkan kepada debitor, membantu kewajiban debitor yakni dengan restrukturisasi kredit maka diharapkan mampu untuk membantu debitor untuk menghidupkan kembali usaha usahanya sehingga dapat melanjutkan kewajibannya membayar kredit kepada kreditor, kemudian dengan dilakukan restrukturisasi kredit maka dapat menghindarkan penyelesaian sengketa melalui lembaga hukum. Adapun restrukturisasi kredit dapat berupa penurunan suku Bunga kredit yang harus dibayarkan oleh debitor, penghitungan kembali bunga kredit yang belum dibayarkan oleh debitor ataupun dihapuskannya tunggakan bunga tersebut secara keseluruhan, perpanjangan waktu kredit dimana dengan adanya perpanjangan waktu kredit akan merubah status kredit yang bermasalah menjadi kredit tidak bermasalah dikarenakan masih adanya waktu bagi debitor untuk dapat melakukan pembayaran terhadap kreditnya tersebut, disamping itu debitor juga dapat memanfaatkan waktu tambahan yang diberikan kreditor untuk memperbaiki usahanya sehingga dapat menghasilkan dana sesuai dengan rencana yang nantinya dapat digunakan untuk melakukan pelunasan utang kepada kreditor, dan pembaharuan utang atau novasi, dimana novasi ini pada prinsipnya membentuk suatu perjanjian baru yang digunakan untuk mengganti perjanjian yang lama, sehingga dengan kemudahan ini akan menghasilkan kesepakatan baru yang diharapkan mampu menguntungkan bagi pihak-pihak terkait untuk menyelesaikan permasalahan yang dihadapi.

\subsection{Tanggung Jawab Debitor Akibat Hapusnya Hak Atas Tanah yang Dibebani Hak Tanggungan}

Kamus Besar Bahasa Indonesia memberikan definisi dari tanggung jawab yakni tanggung jawab merupakan kewajiban untuk menanggung segala sesuatunya dimana bila terjadi apa-apa maka boleh untuk dituntut, dipersalahkan, dan diperkarakan. ${ }^{14}$ Dari definisi tersebut maka secara umum tanggung jawab dapat dipahami sebagai keharusan bagi seseorang untuk menjalankan apa yang menjadi kewajibannya. Penyaluran kredit merupakan kegiatan yang paling menguntungkan bagi bank sehingga dapat menentukan perkembangan dari bank itu sendiri. Dalam menyalurkan kredit kepada masyarakat maka seyogyanya bank haruslah menerapkan prinsip kehati-hatian yaitu dengan cermat dan seksama menganalisis kredit mengingat resiko yang dihadapi serta setelah terjadinya kesepakatan dalam menyalurkan kredit maka bank tetap harus berperan untuk memantau kredit tersebut.

Bank dalam menyalurkan dananya haruslah selalu mengedepankan asas perkreditan yang sehat, namun tidak bisa dipungkiri bahwa upaya bank yang telah melakukan

${ }^{13}$ Saraswati, R. A. (2012). Peranan Analisis Laporan Keuangan, Penilaian Prinsip 5C Calon Debitur dan Pengawasan Kredit terhadap Efektivitas Pemberian Kredit pada PD BPR Bank Pasar Kabupaten Temanggung. Nominal, Barometer Riset Akuntansi dan Manajemen, 1(1).

14 Suharso \& Ana Retnoningsih, 2017, Kamus Besar Bahasa Indonesia Edisi Lux, Widya Karya, Semarang, hal.527 
upaya-upaya yang maksimal untuk menjamin dana yang tersalurkan tersebut akan aman dan akan kembali pada waktunya masih juga bisa juga menjadi kredit yang bermasalah. Menurut Rene Setyawan yang dikutip oleh Rachmadi Usman dalam bukunya menyatakan bahwa permasalahan dalam kegiatan perkreditan dilandasi atas faktor internal dan faktor eksternal. 15

Faktor internal dapat berupa tidak diindahkannya asas-asas perkreditan, prosedur pemberian kredit yang tidak sesuai dengan aturan yang berlaku, kemudian kecurangan oleh pengurus seperti halnya memudahkan penyaluran kredit kepada orang-orang tertentu seperti halnya penyaluran kepada keluarga ataupun kerabat dari pemilik atau pengurus bank. Kaitannya dengan faktor eksternal dapat berupa kegagalan dari usaha yang dijalankan debitor sehingga segala perhitungan yang dilakukan ketika mengajukan kredit menjadi tidak berjalan, adanya musibah yang tidak dapat diprediksi, iklim persaingan di dunia perbankan tidak sehat yang kemudian dimanfaatkan oleh debitor, kesulitan debitor untuk memenuhi kewajibannya karena tingginya nilai suku bunga. Tingginya permasalahan kredit yang dialami oleh bank tentu akan memberikan dampak negative bagi bank itu sendiri selaku pihak yang menyalurkan kredit, serta dampak lebih luas yakni ke dalam dunia perbankan sehingga akan berkaitan dengan ekonomi dari negara. Hal ini juga disampaikan oleh Kasmir yang menyatakan pentingnya dunia perbankan bagi suatu negara, sehingga ada anggapan bahwa bank merupakan "nyawa" dari suatu negara karena dapat menggerakan roda perekonomian serta bank sebagai Lembaga keuangan suatu negara merupakan suatu hal penting dan memiliki posisi yang vital. ${ }^{16}$

Tanggung jawab debitor terkait dengan permasalahan yang dihadapi dalam penelitian ini tidak diatur dengan tegas dalam Undang-Undang Hak Tanggungan. Tetapi dengan hapusnya jaminan dengan hak tanggungan tersebut tidak serta merta menghilangkan utang dari debitor hal ini sesuai dengan pasal 18 ayat (4) UUHT oleh karenanya debitor tetap harus melunasi kreditnya tersebut. Apabila debitor tersebut tidak memenuhi kewajibannya untuk melunasi kreditnya tersebut maka debitor tersebut dapat dikatakan melakukan cidera janji atau wanprestasi. Tidak dipenuhinya perjanjian, keterlambatan dalam pemenuhan perjanjian serta keliru dalam pemenuhan perjanjian merupakan perbuatan-perbuatan yang tergolong sebagai perbuatan wanprestasi. ${ }^{17}$ Sehingga atas dasar perbuatan tersebut maka kreditor memiliki hak untuk menuntut ganti rugi.

\section{Kesimpulan}

Perlindungan bagi kreditor yakni terdiri dari perlindungan preventif yakni perlindungan yang didapatkan oleh masing-masing pihak yang terkandung pada perjanjian kredit. Dengan disepakatinya perjanjian kredit memberikan perlindungan bagi kedua belah pihak guna mencegah terjadinya tindakan yang menimbulkan kerugian bagi para pihak terkait, kemudian adanya asuransi juga memberikan perlindungan bagi kreditor dalam proses penyaluran kredit. Perlindungan represif yakni dilakukan dengan jalan melakukan restrukturisasi kredit sehingga dapat

15 Rachmadi Usman, 2001, Aspek-Aspek Hukum Perbankan di Indonesia, PT. Gramedia Pustaka Utama, Jakarta, Hal.259

${ }^{16}$ Kasmir, 2012, Dasar-Dasar Perbankan Edisi Revisi Ke 10, Rajawali pers, Jakarta, Hal.3

17 Prayogo, S. (2016). Penerapan Batas-Batas Wanprestasi dan Perbuatan Melawan Hukum Dalam Perjanjian. Jurnal Pembaharuan Hukum, 3(2), 280-287.,hal.283 
menjadi solusi bagi para pihak ditambah lagi mampu menghindari penyelesaian sengketa melalui lembaga hukum. Hutang debitor tidak turut serta terhapus dengan hapusnya hak tanggungan yang melekat pada hak atas, hal ini memberikan konsekuensi bahwa debitor tetap berkewajiban untuk melakukan pembayaran hutangnya tersebut hingga lunas sesuai dengan kesepakatan pada perjanjian kredit. Apabila kewajiban dari debitor tersebut tidak dipenuhi maka dapat dikategorikan sebagai tindakan wanprestasi.

\section{Daftar Pustaka \\ Buku}

Djoni S.Gazali \& Rachmadi Usman, 2012, Hukum Perbankan, Sinar Grafika, Jakarta

H. Salim \& Erlies Septiana Nurbani, 2017, Penerapan Teori Hukum Pada Tesis dan Disertasi, PT. RajaGrafindo Persada, Jakarta

Kasmir, 2012, Dasar-Dasar Perbankan Edisi Revisi Ke 10, Rajawali pers, Jakarta.

Rachmadi Usman, 2001, Aspek-Aspek Hukum Perbankan di Indonesia, PT. Gramedia Pustaka Utama, Jakarta.

Soekanto, S. \& Mamudji. S., 2009, Penelitian Hukum Normatif Suatu Tinjauan Singkat, PT Raja Grafindo Persada, Jakarta.

Suharso \& Ana Retnoningsih, 2017, Kamus Besar Bahasa Indonesia Edisi Lux, Widya Karya, Semarang

\section{Jurnal}

Hidayat, D. R. (2018). Perlindungan Hukum bagi Kreditor Dengan Jaminan Atas Objek Jaminan Hak Tanggungan Yang Sama. DiH: Jurnal Ilmu Hukum.

Ivana, M. (2013). Restrukturisasi Kredit oleh PT. Bank Rakyat Indonesia (Persero) Tbk Cabang Kawi Malang terhadap Perusahaan Otobus Putra Mulia Berkedudukan di Kabupaten Malang (Studi Implementasi Surat Keputusan Direksi PT. Bank Rakyat Indonesia No: S. 94-dir/adk/12/2005 T. Kumpulan Jurnal Mahasiswa Fakultas Hukum, 1(4).

Jaya, I. G. P., Utama, I. M. A., \& Westra, I. K. (2015). Kekuatan Hukum Sertifikat Hak Tanggungan Dalam Hal Musnahnya Obyek Hak Tanggungan Karena Bencana Alam. Acta Comitas, 277-285.

Pato, S. (2013). Analisis Pemberian Kredit Mikro Pada Bank Syariah Mandiri Cabang Manado. Jurnal EMBA: Jurnal Riset Ekonomi, Manajemen, Bisnis dan Akuntansi, 1(4).

Pertiwi, d. (2013). Perlindungan hukum pemegang hak tanggungan yang obyeknya dikuasai pihak ketiga berdasarkan perjanjian sewa menyewa. Calyptra, 2(2), 1-16.

Prayogo, S. (2016). Penerapan Batas-Batas Wanprestasi dan Perbuatan Melawan Hukum Dalam Perjanjian. Jurnal Pembaharuan Hukum, 3(2), 280-287.

Saraswati, R. A. (2012). Peranan Analisis Laporan Keuangan, Penilaian Prinsip 5C Calon Debitur dan Pengawasan Kredit terhadap Efektivitas Pemberian Kredit pada PD BPR Bank Pasar Kabupaten Temanggung. Nominal, Barometer Riset Akuntansi dan Manajemen, 1(1).

Sari, G. N. (2013). Faktor-faktor yang mempengaruhi penyaluran kredit bank umum di indonesia (periode 2008.1-2012.2). Jurnal EMBA: Jurnal Riset Ekonomi, Manajemen, Bisnis dan Akuntansi, 1(3).

Winarno, J. (2013). Perlindungan Hukum bagi Kreditor pada Perjanjian Jaminan Fidusia. Jurnal Independent, 1(1). 


\section{Peraturan Perundang-Undangan}

Kitab Undang-Undang Hukum Perdata, 2009, Burgerlijk Wetboek, diterjemahkan oleh Prof. R. Subekti, SH dan R. Tjitrosudibio, Cetakan ke Empatpuluh, Pradnya Paramita, Jakarta.

Republik Indonesia, 1996, Undang-Undang Republik Indonesia Nomor 4 Tahun 1996 tentang Hak Tanggungan Atas Tanah Beserta Benda-Benda yang Berkaitan dengan Tanah (Lembaran Negara Republik Indonesia tahun 1996 Nomor 42, Tambahan Lembaran Negara Republik Indonesia Nomor 3632

Republik Indonesia, 1998, Undang-Undang Republik Indonesia Nomor 10 Tahun 1998 Tentang Perubahan Atas Undang-Undang Nomor 7 Tahun 1992 Tentang Perbankan (Lembaran Negara Republik Indonesia Tahun 1998 Nomor 182, Tambahan Lembaran Negara Republik Indonesia Tahun 1992 Nomor 31, Tambahan Lembaran Negara Republik Indonesia Nomor 3472) 